\title{
Microbial heterotrophs within Codium bursa: a naturally isolated microbial food web
}

\author{
Dolors Vaqué ${ }^{1}$, Susana Agustí ${ }^{2}$, Carlos M. Duarte ${ }^{2}$, Susana Enríquez ${ }^{2}$, Ole Geertz-Hansen ${ }^{3}$ \\ ${ }^{1}$ Institut de Ciències del Mar (CSIC), Passeig Joan de Borbó Comte de Barcelona s/n, E-08039 Barcelona, Spain \\ ${ }^{2}$ Centre d'Estudis Avançats de Blanes (CSIC), Camí de Sta Bàrbara s/n, E-17300 Blanes, Girona, Spain \\ ${ }^{3}$ Freshwater Biological Laboratory, University of Copenhagen, 51 Helsingørsgade, DK-3400 Hillerød, Denmark
}

\begin{abstract}
Codium bursa, a balloon-like chlorophicean macroalga, achieves considerable biomass ( $300 \mathrm{~g} \mathrm{DW} \mathrm{m}^{-2}$ ) in the NW Mediterranean littoral. C. bursa grows as a hollow sphere ranging in size up to $40 \mathrm{~cm}$ in diameter, where the thick algal thallus $(-0.5 \mathrm{~cm})$ encloses a lumen filled with seawater that receives substantial amounts of organic carbon from the thallus. The water enclosed within $C$. bursa supports an active microheterotrophic (bacteria, flagellates and ciliates) community, about 2-fold denser than that in the ambient water, where metazoans are absent. Protistan grazing removed the entire bacterial population daily $\left(121.7 \% \mathrm{~d}^{-1}\right)$. Oxygen concentration within the enclosed water showed large diel fluctuations, reaching concentrations close to saturation ( $90 \%)$ during day time, and concentration close to anoxia (after $12 \mathrm{~h}$ ) in the dark, as a result of the combined metabolism of the alga and the microheterotrophs. The relative activity and abundance of microheterotrophs decreased as $C$. bursa size increased, consistent with the reduction in the ratio of macroalgal weight : internal water volume. That the carbon supplied by the algal enclosure becomes increasingly diluted as $C$. bursa grows was also indicated by reduced exoproteolytic activity with decline of microheterotrophs abundance during $C$. bursa growth. The high heterotrophic activity within $C$. bursa balloons resulted in nutrient concentration 5- to 15 -fold higher than those in the surrounding seawater, which could partially support algal production.
\end{abstract}

KEY WORDS: Microheterotrophs · Grazing · Exoproteolytic activity · Respiration - Macroalgal size Internal water

\section{INTRODUCTION}

Codium bursa J. Agardh is a chlorophycean macroalga that grows in shallow ( 2 to $5 \mathrm{~m}$ depth) sandy and rocky coastal ecosystems of the NW Mediterranean, where it may achieve considerable biomass ( $300 \mathrm{~g} \mathrm{DW}$ $\mathrm{m}^{-2}$, Geertz-Hansen et al. 1994). This macroalga is remarkable because of its spherical form; C. bursa grows as a hollow sphere ranging in size from millimeters up to $40 \mathrm{~cm}$ in diameter (Geertz-Hansen et al. 1994). The lumen enclosed by the thick $(0.5 \mathrm{~cm})$ algal thallus is filled with seawater, and its volume increases as the $3.37 \pm 0.037$ power of the equivalent spherical diameter of the individuals (Geertz-Hansen et al. 1994).

The water contained within Codium bursa balloons should receive substantial amounts of organic carbon from their autotrophic enclosures, which, in turn, should allow high heterotrophic production. The water enclosed within the thick macroalgal thallus contains only heterotrophic microorganisms (bacteria, flagellates and ciliates) (Vaqué unpubl. data). The absence of metazoan that could prey on protists suggests that the latter should be controlled only by prey availability (i.e. bacteria). Hence, the water enclosed within $C$. bursa balloons may act as a natural microcosm where a productive community of microbial heterotrophs encounter refuge from metazoan predation.

Because of the spherical geometry of Codium bursa balloons, the volume of internal water they contain increases faster than macroalgal weight as C. bursa grows (Geertz-Hansen et al. 1994). Consequently, the carbon supplied by the macroalgal enclosure should become increasingly diluted within a relatively greater water volume as $C$. bursa grows. Hence, we hypothesize, based on the geometry of $C$. bursa, that microheterotrophic production in the water enclosed within 
C. bursa balloons should decline relative to the habitat size (i.e. internal water volume), as the macroalga grows.

We test here the expected existence of a dense and productive microbial heterotrophic community in the water enclosed within Codium bursa balloons, and examine the hypothesized size-dependence of their abundance and production. We do so by examining allometric relationships between the equivalent spherical diameter of $C$. bursa balloons and bacterial abundance and activity, protistan abundance and grazing on bacteria, and respiration of heterotrophic communities within the enclosed water. We also examine the time-series of changes in the abundance of bacteria and protists within $C$. bursa to further elucidate the dynamics of this simple food web.

\section{MATERIAL AND METHODS}

Specimens of Codium bursa growing between 2 and $5 \mathrm{~m}$ water depth and encompassing the widest possible size range were collected during November 1992 at Cala Junquet (NE Spain, NW Mediterranean). We measured the displacement volume of individual $C$. bursa balloons to represent their size and to calculate their equivalent spherical diameter (ESD) and the volume of water they contained from allometric equations previously established (Geertz-Hansen et al. 1994). The water enclosed within $C$. bursa was sampled in situ using sterile syringes to estimate the abundance of bacteria (1 to $3 \mathrm{ml}$ sample), flagellates and ciliates (10 to $20 \mathrm{ml}$ sample). We also collected ambient water to compare the abundance and activity of microheterotrophs inside and outside $C$. bursa. The samples for estimating the abundance of bacteria were preserved in formaldehyde ( $0.5 \%$ final concentration) and those for flagellates and ciliates in glutaraldehyde $1 \%$ final concentration).

Specimens used for experiments were transported in refrigerated seawater to the laboratory where they were maintained at in situ water temperature $\left(17^{\circ} \mathrm{C}\right)$ in a $12 \mathrm{~h}$ light (about $300 \mu \mathrm{mol} \mathrm{m} \mathrm{m}^{-2} \mathrm{~s}^{-1}$ ) : $12 \mathrm{~h}$ dark cycle until used as test material to measure respiration rates, bacterial growth, grazing rates on bacteria, and exoproteolytic activity within the internal water. The largest individual collected $(E S D=14.5 \mathrm{~cm})$ was sampled at daily intervals over $17 \mathrm{~d}$ to examine short-term variability in microheterotroph abundance within the enclosed water.

Respiration rates in the water enclosed within Codium bursa were determined from the linear slope of dark oxygen uptake. This was measured using $10 \mathrm{ml}$ samples of enclosed water incubated at $17^{\circ} \mathrm{C}$ placed in a plexiglass chamber fitted with a Clark-type oxygen electrode. To characterize the internal oxygen environment we examined diel fluctuations in oxygen concentration in the water enclosed within an undisturbed medium-sized $C$. bursa $\left(430 \mathrm{~cm}^{3}\right)$ maintained at $17^{\circ} \mathrm{C}$ in a $12 \mathrm{~h} \mathrm{light} \mathrm{(about} 300 \mu \mathrm{mol} \mathrm{m} \mathrm{m}^{-2} \mathrm{~s}^{-1}$ ) : $12 \mathrm{~h}$ dark cycle. This was done by circulating the enclosed water along a closed circuit on line with the oxygen sensor and data logger (sampling frequency $10 \mathrm{~min}$ ), where the water was collected from and returned to the individual lumen through 2 hypodermic needles.

Exoproteolytic activity was assayed fluorimetrically by following the production of $\beta$-naphthylamine in duplicate water subsamples from 9 different Codium bursa (ESD range: 2.37 to $13.05 \mathrm{~cm}$ ), and ambient water adding L-leucil- $\beta$-naphthylamide $(1 \mathrm{mM}$, final concentration) as a substrate (Somville \& Billen 1983).

The abundance of bacteria, heterotrophic flagellates, and ciliates in the enclosed water was determined from several Codium bursa individuals (ESD ranged from 2.37 to $14.5 \mathrm{~cm}$ ) by epifluorescence microscopy at $1250 \times$. Samples were pre-stained with 4,6-diamidino-2-phenylindole (DAPI; Porter \& Feig 1980), and collected on $0.2 \mu \mathrm{m}$ and $0.8 \mu \mathrm{m}$ Nuclepore filters, for bacteria and protists respectively. These counts were performed on duplicate subsamples whenever the volume of enclosed water was sufficient to allow this. We counted bacterial cells in 10 to 20 random fields on each filter, and random $10 \mathrm{~mm}$ strips (86 $\mu \mathrm{m}$ width) for flagellate and ciliate counts.

Rates of grazing on bacteria by heterotrophic flagellates and ciliates in the enclosed water were measured for 8 different Codium bursa individuals with a broad range of sizes (ESD ranged from 2.66 to $14.04 \mathrm{~cm}$ ), as well as in ambient water samples. Grazing experiments were conducted in the laboratory, in incubators at the same in situ temperature. All grazing rates on bacteria were obtained by measuring the rate of disappearance of fluorescently labeled bacteria (FLB) and minicells over $24 \mathrm{~h}$ in water enclosed within $C$. bursa and ambient seawater samples respectively. FLB were prepared from the late stationary phase of cultures of natural bacteria isolated from the NW Mediterranean according to the procedure of Sherr et al. (1987). These starved cells were spherical and their size (average cell volume $0.27 \mu^{3}$ ) closely resembled that of the bacteria enclosed within $C$. bursa (average volume $0.24 \mu^{3}$ ). FLB were then stained with 5-(4,6-dichlorotriazin-2-yl)-aminofluorescein (DTAF) following Sherr et al. (1987), and sonicated, to aid dispersal, prior to use. Ingestion rates on bacteria in the ambient water were measured using a fluorescent minicell technique (Wikner et al. 1986) as modified by Pace et al. (1990). A minicell-producing strain of Escherichia coli was cultured in liquid medium, and minicells were separated using sucrose gradient centrifugation. The minicells 
obtained were spherical and ca $0.5 \mu \mathrm{m}$ diameter (mean volume $=0.065 \mu^{3}$ ), somewhat smaller than open water bacterioplankton (mean volume $=0.15 \mu^{3}$ ). Minicells were then stained with DTAF as FLB (Sherr et al. 1987) and were sonicated before use. FLB solutions were injected, using sterile syringes, into the lumen of each individual alga, and minicells solutions were added to triplicate 2.51 polycarbonate bottles with ambient water at approximately 20 to $50 \%$ of the natural bacterial concentration. We poisoned (final solution of formaldehyde $1 \%$ ) the water enclosed within $1 C$. bursa specimen and 1 sample of ambient water to be used as controls. We collected water samples at $t_{0}$ (time 0 ) and $t_{24}$ (time $24 \mathrm{~h}$ ) in each experiment to determine concentrations of labeled bacteria. Subsamples were preserved with an equal volume of icecold $4 \%$ glutaraldehyde (Sanders et al. 1989). The DTAF-labeled bacteria were counted using epifluorescence microscopy as described above. We also collected samples from the water surrounding the incubated macroalgae to confirm that there was no loss of FLB to the external water.

The time course development of the total number of bacteria ( $N$, cells $\left.\mathrm{ml}^{-1}\right)$ and labeled bacteria $(F$, cells $\mathrm{ml}^{-1}$ ) in the initial (time 0 ) and final (time $t$ ) samples of the experiment were fitted to an exponential model (Marrasé et al. 1992),

$$
\begin{aligned}
& F_{t}=F_{0} \mathrm{e}^{-g t} \\
& N_{t}=N_{0} \mathrm{e}^{a t}
\end{aligned}
$$

to calculate bacterial ingestion rates $\left(g, d^{-1}\right)$, and net growth rates $\left(a, d^{-1}\right)$.

Assuming that FLB and natural bacteria are removed at the same rate, the total number of bacteria grazed during time $t\left(G\right.$, bacteria $\left.\mathrm{ml}^{-1} \mathrm{~d}^{-1}\right)$ can be calculated from the equations above as:

$$
G=g / a\left(N_{t}-N_{0}\right)
$$

Net increase of bacterial abundance, here called net bacterial production (NBP, bacteria $\mathrm{ml}^{-1} \mathrm{~d}^{-1}$ ), can be calculated by the difference between the number of natural bacteria $\left(N_{t}\right.$, cells $\left.\mathrm{ml}^{-1}\right)$ at time $t$ and that of natural bacteria $\left(N_{0}\right.$, cells $\left.\mathrm{ml}^{-1}\right)$ at time zero:

$$
N B P=\left(N_{t}-N_{0}\right)
$$

and gross bacterial production $\left(B P\right.$, bacteria $\left.\mathrm{ml}^{-1} \mathrm{~d}^{-1}\right)$ was calculated as the sum of total grazing $(G)$ and net bacterial production (NBP),

$$
B P=N B P+G \text {. }
$$

These calculations are based on the conservative assumption that all losses of bacteria during the experiments were due to grazing.

Grazing on bacteria in the ambient water was calculated by multiplying the number of minicells disap- pearing over $24 \mathrm{~h}$ by the ratio of initial natural bacteria $\left(N_{0}\right.$, cells $\left.\mathrm{ml}^{-1}\right)$ to added minicells $\left(M_{0}\right.$, cells $\left.\mathrm{ml}^{-1}\right)$,

$$
I=\left(M_{0}-M_{\ell}\right) N_{0} / M_{0}
$$

This simplified model, according to Salat \& Marrasé (1994), yields similar results to the model employed before (Marrasé et al. 1992), when gross growth of bacteria is lower than $0.5 \mathrm{~d}^{-1}$, a case which often occurs in the NW Mediterranean (e.g. $0.09 \mathrm{~d}^{-1}$ to $0.45 \mathrm{~d}^{-1}$; Vaqué unpubl. data).

We examined the size dependence of microheterotroph abundance and activity in the water enclosed within Codium bursa by comparing the slope (b) of the allometric equations relating these properties $(Y)$ to the equivalent spherical diameter of $C$. bursa individuals (ESD),

$$
Y=a \mathrm{ESD}^{b}
$$

to the slope of $3.37 \pm 0.037$ that describes the size dependence of the volume of water enclosed within $C$. bursa (Geertz-Hansen et al. 1994). Slopes significantly smaller and greater than this value indicate that the property examined declines or increases, respectively, relative to the water volume, with increasing $C$. bursa size.

\section{RESULTS AND DISCUSSION}

The water enclosed within Codium bursa supported a dense and active microheterotrophic community, particularly when compared to that in the ambient water (Table 1). Heterotrophic flagellates inside $C$. bursa were abundant but small (about $5 \mu \mathrm{m}$ in diameter) free-living forms, and ciliates were elliptic $(20 \mu \mathrm{m}$ maximum diameter). C. bursa also had a dense population of filamentous cyanobacteria growing between the large cells (utricula) that form the algal balloon (Table 1). These cyanobacteria had a mean biovolume of $1.9 \pm 1.2 \times 10^{6} \mu^{3} \mathrm{~mm}^{-2}$ algal surface (Table 1 ). The presence of a dense cyanobacteria population in the thalli of $C$. bursa and other congeneric species was already known (e.g. Frémy 1934, Rosenberg \& Paerl 1981), to the extent that some cyanobacteria species have only been observed within thalli of $C$. bursa (Frémy 1934). The role of these filamentous cyanobacteria in the nitrogen metabolism of $C$. bursa has not been examined, but their role was found to be negligible in a related Codium species (Rosenberg \& Paerl 1981).

The dense and active microheterotrophic community is probably supported by a substantial supply of organic carbon from the macroalgae, as indicated by the high exoproteolytic activity measured in the enclosed water (Table 1). In turn, there are 2 - to 15 -fold 
Table 1. Codium bursa. Mean \pm SE, range, and number of observations ( $n$ ) of the variables measured in communities enclosed within macroalgal balloons. Mean values measured in the ambient water are also shown. nd: none determined

\begin{tabular}{|c|c|c|c|c|}
\hline Variable & Mean & Range & $\mathrm{n}$ & Ambient \\
\hline Bacterial concentration $\left(10^{6}\right.$ cells $\left.\mathrm{ml}^{-1}\right)$ & $2.94 \pm 0.45$ & $0.59-8.38$ & 27 & 1.1 \\
\hline Flagellate concentration $\left(10^{3}\right.$ cells $\left.\mathrm{ml}^{-1}\right)$ & $1.67 \pm 0.29$ & $0.24-4.46$ & 22 & 1.06 \\
\hline Ciliate concentration (cells $\mathrm{ml}^{-1}$ ) & $61.1 \pm 19.1$ & $10.73-234.2$ & 11 & 34.6 \\
\hline Cyanobacteria $\left(10^{6} \mu \mathrm{m}^{3} \mathrm{~mm}^{-2}\right)$ & $1.9 \pm 1.2$ & $0.26-8.25$ & 6 & nd \\
\hline Respiration rate $\left(m g \mathrm{O}_{2} \mathrm{l}^{-1} \mathrm{~h}^{-1}\right.$ ) & $0.33 \pm 0.06$ & $0.08-0.87$ & 15 & nd \\
\hline Exoproteolytic activity (fluor. units $\mathrm{ml}^{-1} \mathrm{~min}^{-1}$ ) & $2.65 \pm 0.49$ & $1.1-6.0$ & 9 & 0.2 \\
\hline Grazing on bacteria $\left(\% \mathrm{~d}^{-1}\right)$ & $121 \pm 22.7$ & $43.5-232.2$ & 7 & 38.5 \\
\hline Grazing on bacterial production $\left(\% \mathrm{~d}^{-1}\right)$ & $104 \pm 16.8$ & $65.3-179.1$ & 7 & nd \\
\hline
\end{tabular}

Table 2. Codium bursa. Allometric relationships scaling different properties of the microheterotrophic community enclosed within macroalgal balloons to their equivalent spherical diameter (ESD). The regression coefficients $(a$ and $b)$, coefficient of determination $\left(\mathrm{R}^{2}\right), F$-value, and number of observations ( $\mathrm{n}$ ) correspond to the fitted regression equation, $\log$ Property $=a+b \log E S D$ $(\mathrm{cm})$. Asterisks indicate the probability ( $\boldsymbol{t}$-test) that the allometric slope equals that describing the scaling of the volume of water enclosed within balloons to their equivalent spherical diameter $\left(\mathrm{H}_{0}: b=3.37\right)$, and the probability that the relationship examined accounted for a significant fraction of the variance in the property tested respectively. ${ }^{\mathrm{p}}<<0.05 ;{ }^{\cdots} \mathrm{p}<0.0001 ; \mathrm{ns}=\mathrm{p}>0.05$

\begin{tabular}{|c|c|c|c|c|c|}
\hline Property & a & $b$ & $\mathrm{R}^{2}$ & $F$ & $\mathrm{n}$ \\
\hline Bacterial content (cells ind.$^{-1}$ ) & 6.09 & $2.64 \pm 0.22 \cdots$ & 0.85 & $147^{\cdots}$ & 28 \\
\hline Flagellate content (cells ind ${ }^{-1}$ ) & 2.89 & $2.49 \pm 0.37^{\circ}$ & 0.69 & $45.3 \cdots$ & 22 \\
\hline Ciliate content (cells ind. ${ }^{-1}$ ) & 1.72 & $2.29 \pm 0.42^{\circ}$ & 0.75 & $30.3 \cdots$ & 12 \\
\hline Bacteria grazed (cells ind ${ }^{-1} \mathrm{~d}^{-1}$ ) & 6.35 & $2.39 \pm 0.41^{\circ}$ & 0.87 & $33.4^{\cdot}$ & 7 \\
\hline Bacteria produced (cells ind.$^{-1} \mathrm{~d}^{-1}$ ) & 6.47 & $2.24 \pm 0.41$ & 0.86 & $30.5^{\circ}$ & 7 \\
\hline Exoproteolytic activity (fluor units ind ${ }^{-1} \mathrm{~min}^{-1}$ ) & 0.42 & $2.25 \pm 0.23^{\cdots}$ & 0.93 & $96.1 \cdots$ & 9 \\
\hline Microbial respiration $\left(\mathrm{mg} \mathrm{O}_{2}\right.$ ind..$^{-1} \mathrm{~h}^{-1}$ ) & -4.31 & $3.17 \pm 0.27 \mathrm{~ns}$ & 0.91 & $134.4^{\cdots}$ & 15 \\
\hline
\end{tabular}

higher nutrient concentrations in the enclosed water (mean nitrate concentration: $5.42 \mu \mathrm{M}$; phosphate: $1.14 \mu \mathrm{M}_{i}$ and ammonia: $2.05 \mu \mathrm{M}$ ) than in surrounding seawater (nitrate concentration: $0.33 \mu \mathrm{M}$; phosphate: $0.30 \mu \mathrm{M}$; and ammonia: $1.12 \mu \mathrm{M}$ ), which could be used to support algal production. These findings of high abundance and active microheterotrophic community in the water enclosed within $C$. bursa, indicate that

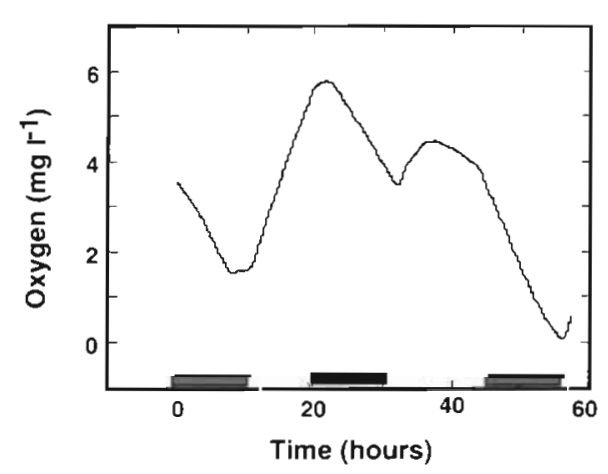

Fig. 1. Codium bursa. Oxygen evolution in the water enclosed within a macroalgal balloon (equivalent spherical diameter, $\mathrm{ESD}=10 \mathrm{~cm}$ ), along $12 \mathrm{~h}$ light : $12 \mathrm{~h}$ dark cycle. Bars indicate darkness these balloons act as refuges of high heterotrophic production within the mostly oligotrophic Mediterranean Sea.

The environment within Codium bursa was characterized by large diel fluctuations in oxygen concentration (Fig. 1). The oxygen released by the macroalga during the day was accumulated in the enclosed water where oxygen concentration reached about $90 \%$ of saturation. In the dark the combined respiration of the alga and the enclosed microheterotrophs depleted oxygen close to anoxia after $12 \mathrm{~h}$ (Fig. 1). The respiration of the internal microbial community is about 10 fold lower than the net production of C. bursa (GeertzHansen et al. 1994), so that the excretion of only about $10 \%$ of the net carbon fixed by the macroalga suffices to support the enclosed microbial community.

The hypothesized size-dependence of the abundance and activity of the microheterotrophs in the enclosed water was supported by our results (Table 2). Bacterial production and abundance, as well as protistan abundance and grazing rates, exoproteolytic activity, and the respiration rate of the bulk community increased with increasing equivalent spherical Codium bursa diameter (Fig. 2). Yet, the abundance and activity of microheteretrophs were scaled as the 

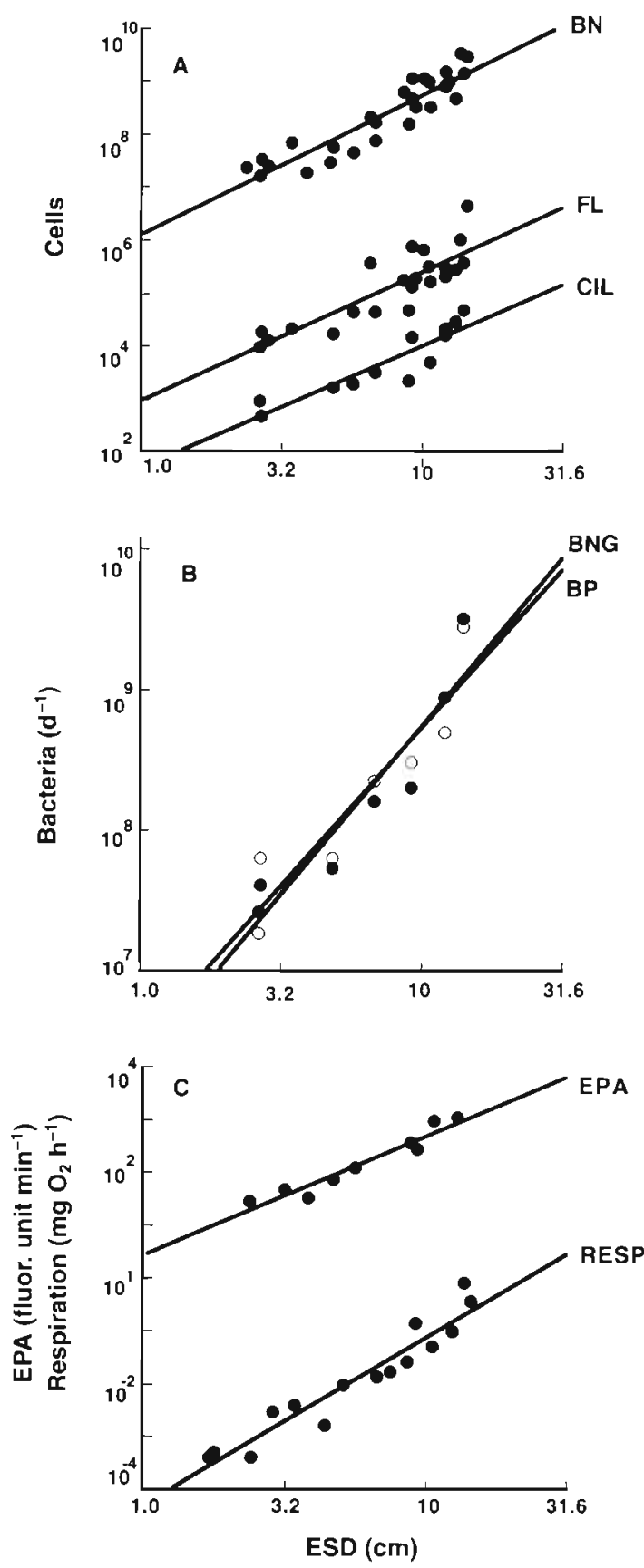

Fig. 2. Codium bursa. Relationship between the equivalent spherical diameter (ESD) of macroalgal balloons and (A) bacteria (BN), flagellate (FL) and ciliate (CIL) abundance; (B) bacterial grazing rates (BNG, $\bullet$ ), and gross bacterial production (BP, O); and (C) bulk community respiration rates (RESP) and exoproteolytic activity (EPA) in the water enclosed within the balloons

2.3 to 2.6 power of $C$. bursa equivalent spherical diameter (Table 2), significantly ( $t$-test, $p<0.001)$ smaller than the rate of increase of the enclosed water volume with $C$. bursa size (slope: $3.37 \pm 0.037$; Geertz-Hansen et al. 1994). Only the bulk community respiration rate was scaled to $C$. bursa ESD with a similar slope not significantly smaller (slope: $3.17 \pm 0.24$, $t$-test, $p>0.05$ ) than the slope which relates the increase of the enclosed water volume with $C$. bursa size (ESD) (slope: $3.37 \pm 0.037$; Geertz-Hansen et al. 1994). Hence, these results indicate that bacterial and protistan abundance and activity tend to decrease relative to the physical size of the community (i.e. the enclosed water volume) as $C$. bursa size increases

The finding of reduced volumetric microheterotrophic activity and population density with increasing Codium bursa size is consistent with our hypothesis, based on the expected increase in the dilution of the substrate supplied by the macroalgae as C. bursa size increases. Indeed, the scaling of microheterotrophic activity and abundance to $C$. bursa size was close to that of macroalgal weight (slope: $2.75 \pm 0.028$, GeertzHansen et al. 1994). Moreover, we have shown (Geertz-Hansen et al. 1994) a deterioration in the nutritional status and growth potential of $C$. bursa macroalgae with increasing size. Large $C$. bursa are less productive per unit biomass than smaller ones, with large $($ ESD $>10 \mathrm{~cm}) C$. bursa supporting maximum photosynthetic rates about 10 -fold lower than small $(1 \mathrm{~cm})$ ones (Geertz-Hansen et al. 1994). Accordingly, the specific release of organic substrates to the enclosed water is expected to decline as $C$. bursa size increases, accounting for the observed reduction in microbial activity and abundance in large $C$. bursa. In addition to this, the organic matter released should be increasingly diluted in the proportionately larger water volume enclosed within large $C$. bursa

The similar scaling observed for bacteria and protistan abundance and activity suggests a positive relationship between the concentrations of bacteria and their protistan predators, and exoproteolytic activity in the enclosed water. This was supported by the finding of significant positive correlation (Fig. 3) between bacterial concentration and that of heterotrophic flagellates $(r=0.66, n=24, p<0.0001)$, and ciliates $(r=0.77$, $\mathrm{n}=13, \mathrm{p}=0.002)$. Also, exoproteolytic activity increased when bacterial abundance increased $(r=0.75$, $\mathrm{n}=6, \mathrm{p}=0.05$ ), although heterotrophic flagellates may also contribute to this effect by releasing digestive enzymes (Nagata \& Kirchman 1992). Bacterial activity appears to be controlled by the supply rate of organic exudates by the macroalga, and protistan abundance appears to be regulated by the concentration of their bacterial prey, particularly since we observed no metazoan predators.

Protists should mainly be regulated by prey (i.e. bacteria) availability if they are bacterivores and could decimate the bacterial population in the enclosed water to limiting levels. This possibility was examined by quantifying protistan bacterivory in situ, which 

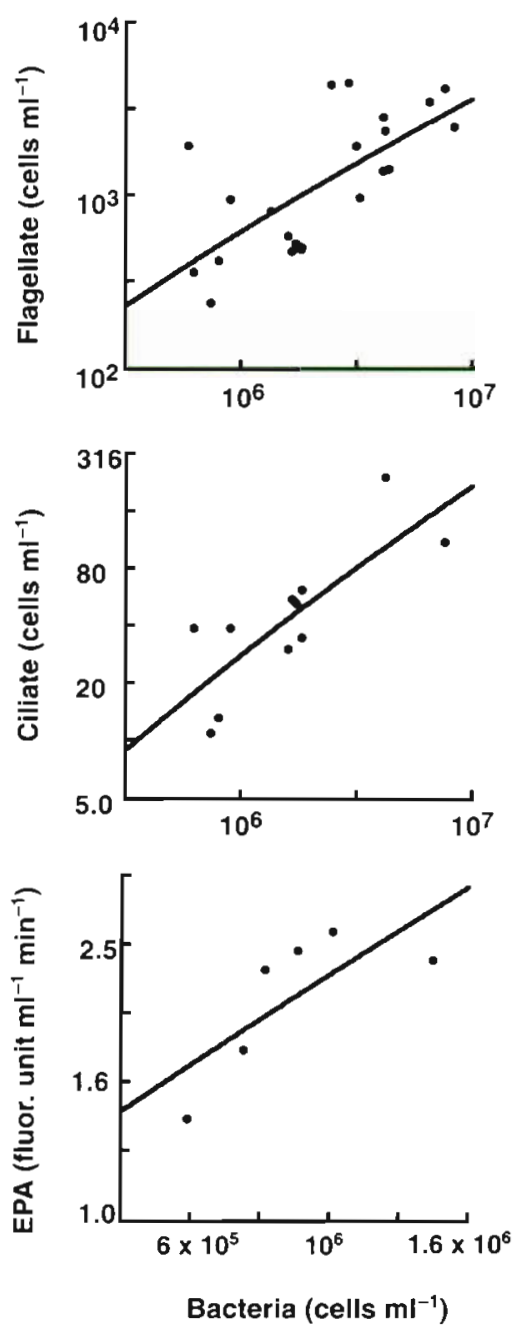

Fig. 3. Codium bursa. Relationship between abundance of flagellates and ciliates, and exoproteolytic activity with bacterial abundance within macroalgal balloons confirmed that protists' vacuoles filled with FLB after $24 \mathrm{~h}$. The calculated protistan bacterivory rates were very high, for they were able to remove the entire bacterial population in $1 \mathrm{~d}$ (Table 1). Furthermore, no significant change in FLB and minicell abundance was detected in poisoned controls, and no FLB were detected in the surrounding seawater, confirming that the decline of FLB following incubation was attributable to grazing rather than leakage from the Codium bursa. The grazing rates found inside C. bursa are much higher than those in the ambient waters (Table 1) and values reported for other planktonic populations, where grazers remove between 7 and $40 \%$ of the bacterial population daily (Table 3 ). The dense bacterial population in the water enclosed within C. bursa is maintained by the high production rates, which allow a turnover rate of the bacterial population of $>1 \mathrm{~d}^{-1}$ (range $=0.7$ to $2.3 \mathrm{~d}^{-1}$ ).

Grazing rates on bacteria tended to increase with the concentration of heterotrophic flagellates $(r=0.82$, $\mathrm{n}=7, \mathrm{p}<0.01)$ and ciliates $(\mathrm{r}=0.72, \mathrm{n}=7, \mathrm{p}<0.05)$. Hence, bacterial abundance in this natural enclosure is apparently controlled by protistan grazing (top-down). Protists could also exhibit trophic interactions between them, since there is evidence that ciliates can prey on heterotrophic flagellates (Verity 1991) and that large flagellates can feed on smaller ones (Goldman \& Caron 1985, Wikner \& Hagström 1988). The microheterotrophic community enclosed within Codium bursa represents, however, a simplified microbial food web, where metazoan (e.g. copepods) were absent.

A simple predator-prey system where predators are limited by prey availability, such as the microbial food web enclosed within Codium bursa, may exhibit periodic fluctuations, as predicted by models (cf. Margalef 1980). Our time series of daily changes in bacteria and

Table 3. Bacterial grazing rates (as the percent of the populations preyed upon daily; average and range) in different aquatic ecosystems (F: freshwater; E: estuarine; C: coastal; OS: open sea)

\begin{tabular}{|c|c|c|c|}
\hline $\begin{array}{l}\text { Ecosystem } \\
\text { location }\end{array}$ & $\begin{array}{l}\text { Ecosystem } \\
\text { type }\end{array}$ & Bacteria grazed & Source \\
\hline Upton Lake, NY, USA & $\mathrm{F}$ & $17.10(11-40)$ & Pace et al. (1990) \\
\hline Lake Oglethorpe, GA, USA & $\mathrm{F}$ & $10.15(2-35)$ & $\begin{array}{l}\text { Sanders et al. (1989) } \\
\text { Bennet et al. (1990) }\end{array}$ \\
\hline Butron River, Spain & $\mathrm{F}$ & $13.28(0.79-33)$ & Barcina et al. (1991) \\
\hline Ogeechee River, GA, USA & $F$ & $32.55(5-52)$ & Carlough \& Meyer (1989) \\
\hline Ogeechee River, GA, USA & $\mathrm{F}$ & $19.93(0.22-104)$ & Carlough \& Meyer (1990) \\
\hline Hudson River, NY, USA & $E$ & $20.40(15-34)$ & Vaqué et al. (1992) \\
\hline Woods Hole, MA, USA & $\mathrm{C}$ & $10.20(3-61)$ & Marrasé et al. (1992) \\
\hline NW Mediterranean, Spain & $\mathrm{C}$ & $38.70(5-80)$ & Vaqué et al. (unpubl.) \\
\hline NW Mediterranean, Spain & OS & $10.54(0.55-24)$ & Vaqué et al. (unpubl.) \\
\hline $\begin{array}{l}\text { Enclosed community within } \\
\text { Codium bursa balloons }\end{array}$ & & $121.70(43-232)$ & This study \\
\hline
\end{tabular}




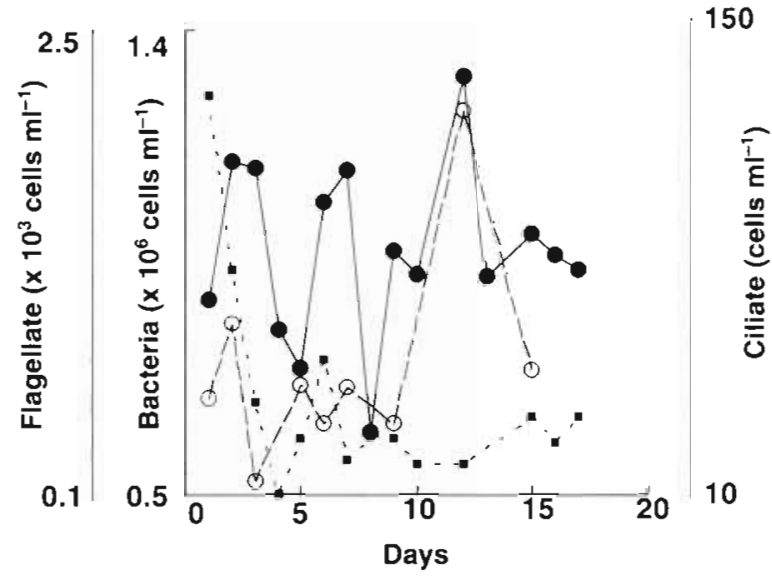

Fig. 4. Codium bursa. Daily fluctuations of heterotrophic microorganisms inside of a large macroalgal balloon $(\mathrm{ESD}=$ $14 \mathrm{~cm}$ ). (-) Bacterial abundance; ( 1 ) flagellate abundance; (O) ciliate abundance

protists from a medium size $C$. bursa $(E S D=14.5 \mathrm{~cm})$ did show some fluctuations (Fig. 4), which were most evident for bacterial abundance. Bacterial abundance fluctuated with a period of about $4 \mathrm{~d}$, whereas heterotrophic flagellates and ciliates showed longer-term changes in abundance along the observational period (Fig. 4). The changes in bacteria and protists deviate, however, from those expected under simple LotkaVolterra dynamics, where predators and prey should fluctuate with the same period, albeit out of phase (cf. Margalef 1980). This suggests the microheterotrophic food web to be somewhat complex, particularly if ciliates were capable of consuming flagellates (Weisse 1990, Verity 1991, K. Jürgens pers. comm.).

This enclosed microbial food web is unique in several aspects. Firstly, this microbial food web offers excellent opportunities to examine, and manipulate, interactions between undisturbed bacteria and protistan communities. Secondly, the enclosed bacterial population exhibited very fast turnover rates, matched by protistan grazing rates which were several fold greater than values reported for any other microbial food web (Table 3). Hence, protists were responsible for virtually all of the losses of the enclosed bacterial population, whereas such a primary role of protistan grazing in controlling bacterial populations is only evident for other marine systems when organisms that prey on protists are removed (Andersen \& Fenchel 1985, Bloem \& Bär-Gilisen 1989). Lastly, Codium bursa balloons support a tightly coupled autotrophic and heterotrophic production, as ensured by the close contact between both system components, which should lead to a high nutrient efficiency and substantial recycled autotrophic production. C. bursa balloons act, therefore, as microcosms of high heterotrophic production within an oligotrophic sea.
Acknowledgements. This work was supported by grant MAR91-0503 of CICYT (Spanish Interministerial Research Commission) to C.M.D. We thank Enrique Ballesteros for advice, and Kaj Sand-Jensen for useful comments. We also thanks to C. Marrasé and R. Massana who kindly provided the FLB used in this study.

\section{LITERATURE CITED}

Andersen, P., Fenchel, F. (1985). Bacterivory by microheterotrophic flagellates in seawater samples. Limnol. Oceanogr. 30: $198-202$

Barcina, I., Ayo, B., Muela, A., Egea, L., Iriberri, J. (1991). Predation rates of flagellate and ciliated protozoa on bacterioplankton in a river. Microbiol. Ecol. 85: 141-150

Bennet, S. J., Sanders, R. W., Porter, K. G. (1990). Heterotrophic, autotrophic, and mixotrophic nanoflagellates: seasonal abundances and bacterivory in a eutrophic lake. Limnol. Oceanogr. 35: 1821-1832

Bloem, J., Bär-Gilissen, M-J. B. (1989). Bacterial activity and protozoan grazing potential in a stratified lake. Limnol. Oceanogr. 35: 1821-1832

Carlough, L. A., Meyer, J. L. (1989). Protozoans in two southwestern blackwater rivers and their importance to trophic transfer. Limnol. Oceanogr. 34: 163-177

Carlough, L. A., Meyer, J. L. (1990). Rates of protozoan bacterivory in three habitats of a southeastern blackwater river. J. N. Am. Benthol. Soc. 9: 45-53

Frémy, P. (1934). Les Cyanophycées des côtes d'Europe. Saint-Lo, Paris.

Geertz-Hansen, O., Enríquez, S., Duarte, C. M., Agustí, S., Vaqué, D. Vidondo, B. (in press). Functional implications of Codium bursa form, a balloon-like Mediterranean macroalga. Mar. Ecol. Prog. Ser. 108: 153-160

Goldman, J. C., Caron, D. A. (1985). Experimental studies on an omnivorous microflagellate: implications for grazing and nutrient regeneration in the marine microbial food chain. Deep Sea Res. 32: 899-915

Margalef, R. (1980). Ecología, 3rd edn. Omega, Barcelona

Marrasé, C., Lim, E. I., Caron, D. A. (1992). Seasonal and daily changes in bacterivory in a coastal plankton community. Mar. Ecol. Prog. Ser. 82: 281-289

Nagata, T., Kirchman, D. L. (1992). Release of macromolecular organic complexes by heterotrophic marine flagellates. Mar. Ecol. Prog. Ser. 83: 233-240

Pace, M. L., McManus, G. B., Findlay, S. E. G. (1990). Planktonic community structure determines the fate of bacterial production in a temperate lake. Limnol. Oceanogr. 35: 795-808

Porter K. G., Feig, Y. S. (1980). The use of DAPI for identifying and counting aquatic microflora. Limnol. Oceanogr. 25: 943-948

Rosenberg, G., Paerl, H. W. (1981). Nitrogen fixation by bluegreen associated with the siphonous green seaweed Codium decotircatum: effects on ammonium uptake. Mar. Biol. 61: 151-158

Salat, J., Marrasé, C. (1994). Exponential and linear estimations of grazing of bacteria: effects of changes in the proportion of marked cells. Mar. Ecol. Prog. Ser. 104: 205-209

Sanders, R. W., Porter, K. G., Bennett, S. J., DeBiasse, A. E. (1989). Seasonal patterns of bacterivory by flagellates, ciliates, rotifers, and cladocerans in a freshwater planktonic community. Limnol. Oceanogr. 34: 673-687

Sherr, B. F., Sherr, E. B., Fallon, R. D. (1987). Use of monodispersed, fluorescently labeled bacteria to estimate in situ protozoan bacterivory. Appl. environ. Microbiol. 53: 958-965 
Somville, M., Billen, G. (1983). A method for determining exoproteolytic activity in natural waters. Limnol. Oceanogr. 28: $190-193$

Vaqué, D., Pace, M. L., Findlay, S. E. G., Lints, D. (1992.) Fate of bacterial production in a heterotrophic ecosystem: grazing by protists and metazoans in the Hudson Estuary. Mar. Ecol. Prog. Ser. 89: 155-163

Verity, P. G. (1991). Measurement and simulation of prey uptake by marine planktonic ciliates fed plastidic and aplastidic nanoplankton. Limnol. Oceanogr. 36: $729-750$

This article was submitted to the editor
Weisse, T. (1990). Trophic interactions among heterotrophic microplankton, nanoplankton and bacteria in Lake Constance. Hydrobiology 191: 111-122

Wikner, J., Andersson, A., Normark, S., Hagström. A. (1986). Use of genetically marked minicells as a probe in measurements of predation on bacteria in aquatic environments. Appl. environ. Microbiol. 52: 4-8

Wikner, J., Hagström, $\AA$. (1988). Evidence for a tightly coupled nanoplanktonic predator-prey link regulating the bacterivores in the marine environment. Mar. Ecol. Prog. Ser. 50: 137-145

Manuscript first received: December 14, 1993 Revised version accepted: March 29, 1994 